\title{
Improving Science Learning Outcomes through the Application of Discovery Learning Learning Models to Grade V Students of SD Negeri Ayah
}

\section{Khikmah Fauziyati}

SD Negeri Ayah

khikmahfauziyati@gmail.com

\section{Article History}

accepted 01/11/2020

approved 08/11/2020

published 15/11/2020

\begin{abstract}
The purpose of this study was to improve student learning outcomes in science muple class $V$ elementary schools through the application of the Discovery Learning learning model. The research conducted was a Classroom Action Research (CAR) consisting of three cycles, with each cycle consisting of four stages, namely planning, implementing, observing and reflecting. The implementation of the action uses the Discovery Learning model with a systematics of initial activities, core activities, and final activities. The results showed that the application of the Discovery Learning model resulted in a successful increase in learning outcomes. The percentage of completeness of science learning outcomes has increased which in the pre cycle was $33 \%$, then in the first cycle it became $58.3 \%$, in the second cycle it reached $83.3 \%$, and in the third cycle it reached 92\%. Based on the learning outcomes, it can be concluded that applying the Discovery Learning model can improve the learning outcomes of grade V SD Negeri Ayah students.
\end{abstract}

Keywords: Learning outcomes, Discovery Learning, Science

\begin{abstract}
Abstrak
Tujuan dari penelitian ini adalah untuk meningkatkan hasil belajar peserta didik pada mupel IPA di sekolah dasar kelas $\mathrm{V}$ melalui penerapan model pembelajaran Discovery Learning. Penelitian yang dilakukan adalah Penelitian Tindakan Kelas (PTK) sebanyak tiga siklus, dengan masing masing siklus terdiri dari empat tahap yaitu perencanaan, pelaksanaan, observasi dan refleksi. Pelaksanaan tindakan menggunakan model Discovery Learning dengan sistematika kegiatan awal, kegiatan inti, dan kegiatan akhir. Hasil penelitian menunjukkan bahwa penerapan model Discovery Learning terjadi keberhasilan peningkatan hasil belajar. Persentase ketuntasan hasil belajar IPA mengalami peningkatan yang pada pra siklus 33\%, kemudian pada siklus I menjadi 58,3 , pada siklus II mencapai $83,3 \%$, dan pada siklus III mencapai $92 \%$. Berdasarkan hasil belajar tersebut dapat disimpulkan bahwa dengan menerapkan model Discovery Learning dapat meningkatkan hasil belajar peserta didik kelas V SD Negeri Ayah.
\end{abstract}

Kata kunci: Hasil belajar, Discovery Learning, IPA

Social, Humanities, and Education Studies (SHEs): Conference Series https://jurnal.uns.ac.id/shes

p-ISSN 2620-9284

e-ISSN 2620-9292 


\section{PENDAHULUAN}

Proses belajar mengajar diharapkan dapat memberikan pengalaman kepada siswa sebagai subjek belajar. Selain itu, pembelajaran diharapkan dapat memberikan bekal bagi siswa untuk hidup di masyarakat baik sikap, pengetahuan, dan keterampilan. Upaya untuk memperoleh pengalaman diperlukan adanya interaksi yang efektif baik antara guru dengan siswa, antara siswa dengan siswa, maupun antara siswa dengan lingkungan belajarnya untuk dapat mencapai tujuan pembelajaran. Guru berperan sebagai fasilitator yang bertugas untuk mendorong siswa aktif dalam upaya memperoleh pengalaman. Pembelajaran tidak hanya sebatas transfer of knowledge tetapi juga membutuhkan proses aktif siswa untuk membangun sendiri pengetahuannya.

IImu Pengetahuan Alam (IPA) sebagai salah satu muatan pelajaran yang mengantarkan siswa dalam proses perubahan perilaku sebagai hasil interaksi dengan lingkungannya untuk mencapai tujuan. Oleh karena itu diperlukan adanya partisipasi aktif siswa dalam pembelajaran sebagai upaya untuk memperoleh pengalaman. Sri Sulistyorini dan Supartono dalam Sriyanti (2015:1) menyatakan konsep pendidikan dalam pembelajaran IPA yaitu pendekatan atau metode pembelajaran harus memberi kemungkinan agar siswa dapat menunjukkan keaktifan penuh dalam belajar (active learning). Selain itu proses pendidikan yang diciptakan dari suatu metode harus menciptakan suasana menyenangkan bagi siswa sehingga siswa dapat belajar secara nyaman dan gembira (joyfull learning).

Namun berdasarkan pengalaman peneliti di Kelas V, SD Negeri Ayah Kecamatan Ayah Kabupaten Kebumen Tahun Pelajaran 2020/2021 proses pembelajaran tidak berlangsung sebagaimana mestinya. Kegiatan pembelajaran hanya melibatkan siswa tertentu yang aktif sedangkan siswa yang lain kurang memperhatikan pelajaran. Ketika guru mengajukan pertanyaan, sebagian besar siswa tidak dapat menjawab pertanyaan yang diberikan, 8 siswa dari 12 siswa di Kelas V pasif dalam mengikuti pembelajaran. Kurangnya inovasi dalam pembelajaran menjadikan beberapa siswa terlihat bosan, hal tersebut terlihat ketika guru memberikan kesempatan bertanya tetapi tidak ada satu siswapun yang bertanya. Hal tersebut menunjukkan rasa keingintahuan siswa yang masih rendah. Hal ini terjadi karena guru terkesan mendominasi pada pembelajaran daring (teacher center). Hal tersebut menyebabkan motivasi belajar siswa rendah dan akhirnya prestasi belajar belum memuaskan. Terbukti nilai Ulangan Harian muatan pelajaran IPA 8 siswa dari 12 siswa memperoleh nilai di bawah Kriteria Ketuntasan Minimal (KKM). Berdasarkan data hasil belajar diatas maka dibutuhkan suatu tundakan yang ditujukan untuk mengatasi permasalahan pembelajaran tersebut serta meningkatkan hasil belajar IPA.

Peneliti bersama kolaborator menetapkan model pembelajaran inovatif yang dapat meminimalisasi permasalahan pembelajaran dan meningkatkan kualitas pembelajaran yaitu dengan penerapan model Discovery Learning melalui Zoom Meeting. Hal tersebut dikarenakan melalui model Discovery Learning dapat melatih siswa belajar secara aktif, analitis, terampil merumuskan dan memecahkan permasalahan melalui kegiatan penemuan informasi sendiri serta memfasilitasi kemampuan siswa untuk berpikir dan mempresentasikan apa yang dipahami sesuai dengan tingkat perkembangannya sehingga pembelajaran menjadi lebih bermakna. Kualitas pembelajaran diartikan sebagai indikator penentu keberhasilan pembelajaran. Menurut Hamdani (2011:295) kualitas pembelajaran adalah kualitas implementasi program yang telah dirancang sebelumnya. Depdiknas (2004: 7-10) menyatakan kualitas pembelajaran terdiri dari beberapa komponen: (1) keterampilan guru; (2) materi pembelajaran; (3) iklim pembelajaran; (4) media pembelajaran; (5) aktivitas siswa; dan (6) hasil belajar. Penelitian ini mengkaji komponen tersebut dalam 3 (tiga) variabel penelitian, meliputi: keterampilan guru, aktivitas siswa, dan hasil belajar siswa. 
Dari kenyataan itulah yang mendorong penulis untuk menggunakan model Discovery Learning yang merupakan salah satu model pembelajaran berbasis student center dalam pembelajaran IImu Pengetahuan Alam dengan harapan hasil belajar dalam muatan pelajaran IPA dapat meningkat.

Berdasarkan latar belakang masalah, maka dirumuskan masalah sebagai fokus penelitian perbaikan pembelajaran yaitu "Bagaimana hasil belajar siswa pada muatan pelajaran IPA setelah dilaksanakan pembelajaran menerapkan model Discovery Learning pada siswa Kelas V SD Negeri Ayah Kecamatan Ayah Kabupaten Kebumen?

Tujuan penelitian ini adalah untuk meningkatkan hasil belajar siswa pada muatan pelajaran IPA melalui penerapan model Discovery Learning pada siswa Kelas V SD Negeri Ayah Kecamatan Ayah Kabupaten Kebumen.

\begin{abstract}
METODE
Penelitian ini adalah penelitian tindakan kelas (Classroom Action Research) dengan menerapkan model pembelajaran Discovery Learning. Menurut Kurt Lewin dalam Kunandar (2011: 42) penelitian tindakan kelas ini terdiri dari empat tahapan dasar yaitu perencanaan (planning), pelaksanaan (acting), pengamatan (observing) dan refleksi (reflecting). Penelitian ini dilaksanakan pada peserta didik kelas V SD Negeri Ayah Tahun Pelajaran 2020/2021 selama tiga siklus secara daring dengan jumlah peserta didik 12 peserta didik yang terdiri dari 8 peserta didik perempuan dan 4 peserta didik laki-laki. Siklus I dilaksanakan pada tanggal 22 Oktober 2020. Siklus II dilaksanakan pada tanggal 2 November 2020. Siklus III dilaksanakan pada tanggal 13 November 2020. Pengumpulan data dilakukan dengan menggunakan tes dan nontes. Tes dalam bentuk pilihan ganda untuk mengetahui penguasaan konsep belajar siswa. Nontes berupa lembar observasi. Data observasi kegiatan pembelajaran untuk melihat keterlaksanaan model pembelajaran discovery learning yang diterapkan
\end{abstract}

\title{
HASIL DAN PEMBAHASAN
}

Pada siklus I pembelajaran dilaksanakan selama satu pertemuan, setiap pertemuan diadakan evaluasi sebagai tolak ukur keberhasilan terhadap usaha perbaikan yang dilakukan guru dengan menerapkan model Discovery Learning pada muatan pelajaran IPA. Pembelajaran dengan model Discovery Learning dilaksanakan dengan 6 langkah (syntak) secara berurutan mulai dari stimulation, identifikasi masalah, pengumpulan data, pengolahan data, pembuktian, dan menarik kesimpulan. Berikut ini adalah hasil belajar peserta didik pada siklus I yang bisa dilihat pada tabel berikut.

Tabel 1. Hasil Belajar Peserta Didik Siklus I

\begin{tabular}{c|c|c|c|c|c}
\hline \multirow{2}{*}{ Nilai } & \multirow{2}{*}{ Jumlah siswa } & \multicolumn{2}{|c|}{ keterangan } & \multicolumn{2}{c}{ Persentase nilai } \\
\cline { 3 - 6 } & & tuntas & $\begin{array}{c}\text { Tidak } \\
\text { tuntas }\end{array}$ & tuntas & $\begin{array}{c}\text { Tidak } \\
\text { tuntas }\end{array}$ \\
\hline$\geq 70$ & $\mathbf{7}$ & $\sqrt{ }$ & $\mathbf{5 8 \%}$ & \\
$<70$ & 5 & & $\sqrt{ }$ & \\
jumlah & 12 & & & & \\
\hline
\end{tabular}

Berdasarkan tabel di atas maka terjadi peningkatan antara prasiklus dan siklus 1 . Setiap individu peserta didik sudah mengalami peningkatan hasil belajarnya. Berdasarkan data hasil evaluasi siklus I, dari 12 peserta didik yang mengikuti pembelajaran hanya 7 peserta didik yang mampu mencapai nilai (70-100). Dan 
sisanya 5 peserta didik belum berhasil mencapai nilai (nilai kurang dari 70). Pada siklus 1 tingkat keberhasilan pada hasil belajar siswa mencapat 7 siswa yang artinya hasil siswa yang masuk pada kategori tuntas ada 58\% dari total siswa di kelas. Kriteria keberhasilan dari penelitian ini yaitu jika $80 \%$ dari keseluruhan siswa telah mencapai kriteria Ketuntasn Minimal (KKM) yaitu sebesar 70. Dari hasil prestasi siwa pada siklus 1 belum tercapai keberhasilan dari penelitian ini maka perlu diadakan perbaikan pembelajaran pada siklus berikutnya.

Berdasarkan refleksi pada siklus I maka diputuskan untuk melanjutkan ke siklus II dikarenakan belum mencapai ketuntasan klasikal yang diharapkan. Pembelajaran dengan model Discovery Learning dilaksanakan dengan 6 langkah (syntak) secara berurutan seperti siklus I. Berikut ini adalah hasil belajar peserta didik pada siklus II yang bisa dilihat pada tabel berikut.

Tabel 2. Hasil Belajar Peserta Didik Siklus II

\begin{tabular}{c|c|c|c|c|c}
\hline \multirow{2}{*}{ Nilai } & \multirow{2}{*}{ Jumlah siswa } & \multicolumn{2}{|c|}{ keterangan } & \multicolumn{2}{c}{ Persentase nilai } \\
\cline { 3 - 6 } & & tuntas & $\begin{array}{c}\text { Tidak } \\
\text { tuntas }\end{array}$ & tuntas & $\begin{array}{c}\text { Tidak } \\
\text { tuntas }\end{array}$ \\
\hline$\geq 70$ & $\mathbf{1 0}$ & $\sqrt{ }$ & $\mathbf{8 3 \%}$ & \\
$<70$ & 2 & & $\sqrt{ }$ & $17 \%$ \\
jumlah & 12 & & & & \\
\hline
\end{tabular}

Dari hasil diatas terlihat bahwa pada siklus II keberhasilan pada hasil belajar peserta didik mencapai 10 peserta didik yang artinya hasil belajar peserta didik yang masuk pada kategori tuntas ada $83 \%$ dari total peserta didik di kelas. Kriteria keberhasilan dari penelitian ini yaitu jika nilai $80 \%$ dari keseluruhan siswa telah mencapai Kriteria Ketuntasan Minimal (KKM) yaitu sebesar 70.

Sesuai dengan refleksi pembelajaran pada siklus II yang sudah dilakukan maka perlu penguatan kembali penerapan model discovery learning pada muatan pelajaran IPA kelas V SD Negeri Ayah yang dilakukan pada siklus III. Hasil belajar peserta didik dapat dilihat pada tabel berikut.

Tabel 3. Hasil Belajar Peserta Didik Siklus III

\begin{tabular}{c|c|c|c|c|c}
\hline \multirow{2}{*}{ Nilai } & \multirow{2}{*}{ Jumlah siswa } & \multicolumn{2}{|c|}{ keterangan } & \multicolumn{2}{c}{ Persentase nilai } \\
\cline { 3 - 6 } & & tuntas & $\begin{array}{c}\text { Tidak } \\
\text { tuntas }\end{array}$ & tuntas & $\begin{array}{c}\text { Tidak } \\
\text { tuntas }\end{array}$ \\
\hline $\mathbf{7 0}$ & $\mathbf{1 1}$ & $\sqrt{ }$ & $\mathbf{9 2} \%$ & \\
$<70$ & 1 & & $\sqrt{ }$ & \\
jumlah & 12 & & & & \\
\hline
\end{tabular}

Dari hasil diatas terlihat bahwa pada siklus III keberhasilan pada hasil belajar peserta didik mencapai 11 peserta didik yang artinya hasil belajar peserta didik yang masuk pada kategori tuntas ada $92 \%$ dari total peserta didik di kelas. Kriteria keberhasilan dari penelitian ini yaitu jika nilai $80 \%$ dari keseluruhan siswa telah mencapai Kriteria Ketuntasan Minimal (KKM) yaitu sebesar 70.

Dari tiga siklus yang sudah dilaksanakan dapat dipastikan bahwa model pembelajaran Discovery Learning dapat meningkatkan hasil belajar peserta didik pada mupel IPA kususnya materi rantai makanan pada peserta didik Kelas V di SD Negeri Ayah. Hal ini sejalan dengan pendapat Hosnan, (2013:282) mengartikan pembelajaran discovery learning sebagai berikut : Discovery learning adalah suatu model untuk mengembangkan cara belajar siswa aktif dengan menemukan sendiri, menyelidiki sendiri, maka hasil yang akan diperoleh akan setia dan tahan lama dalam ingatan, tidak akan mudah dilupakan siswa. 


\section{SIMPULAN}

Penerapan model pembelajaran Discovery Learning dapat meningkatkan hasil belajar peserta didik kelas $V$ pada mupel IPA. Hal ini dibuktikan dari hasil observasi yang menunjukan bahwa hasil belajar dari 12 peserta didik hanya 4 peserta didik yang tuntas (33\%) dan sisanya 8 peserta didik belum tuntas (67\%). Setelah dilaksanakan tindakan menggunakan model discovery learning pada siklus I membuktikan bahwa hasil belajar peserta didik mengalami peningkatan. Hasil belajar dari 12 peserta didik 7 peserta didik (58\%) tuntas dan 5 peserta didik (42\%) belum tuntas.pada siklus II hasil belajar peserta didik menunjukkan 10 peserta didik (83\%) tuntas dan 2 peserta didik (17\%) belum tuntas. Dan pada siklus III hasil belajar peserta didik menunjukkan dari 12 peserta didik 11 diantaranya (92\%) tuntas dan hanya 1 peserta didik (85) belum tuntas. Berdasarkan hasil tersebut, dapat dinyatakan bahwa penerapan model Discovery learning dapat meningkatkan hasil belajar muatan pelajaran IPA pada peserta didik kelas V SD Negeri Ayah Kecamatan Ayah Kabupaten Kebumen Tahun Pelajaran 2020/2021.

\section{DAFTAR PUSTAKA}

AgusTianasari, Candra Diah. Peningkatan Kualitas Pembelajaran IPS Melalui Model Discovery Learning Berbantuan Media Audiovisual Pada Siswa Kelas VB SDN Ngaliyan 01 Semarang.Diunduh tanggal 13 Oktober 2020. http://lib.unnes.ac.id/21661/1/1401411246-s.pdf

Arikunto, S., Suhardjono, Supardi. (2010). Penelitian Tindakan Kelas. Jakarta: Bumi Aksara.

Hamdani. 2011. Strategi Belajar Mengajar. Bandung: Pustaka Setia Universitas Terbuka

Hosnan. 2013. Model Discovery Learning. Diakses dari halaman web tanggal 21 november 2020 dari eprints.ums.ac.id/34435///NASKAH\%20PUBLIKASI.pdf

Kemendikbud. 2013. Kerangka Dasar Kurikulum 2013. Jakarta: Kementerian Pendidikan dan Kebudayaan tahun 2013 Badan Standar Nasional Pendidikan Diunduh 20 Oktober 2020 http://edutaka.blogspot.com/2015/03/pembelajarantematik.html

Kemmis, S. \& McTaggart, R. (1997). The action research planner, Deaken University

PG Dikdas - Implementasi Kurikulum 2013 menurut Permendikbud Nomor 22 Tahun 2016 . Diunduh 20 Oktober 2020 http://pgdikdas.kemdikbud.go.id/readnews/mengenal-model-pembelajaran-discovery-learning

Rusman. 2011. Model-Model Pembelajaran: Membangun Profesinalisme Guru. Jakarta: Rajawali Pers

Suprijono, Agus. 2012. Cooperative Learning: Teori dan Aplikasi PAIKEM. Yogyakarta: Pustaka Pelajar

Winataputra, Udin S. 2008. Teori Belajar dan Pembelajaran. Jakarta:

Bertema - Sintaks Sintak model Discovery Learning Dalam Pembelajaran. Diunduh 20 Oktober 2020 https://bertema.com/sintaks-model-discovery-learning 